УДК 316.344 .23

DOI 10.52575/2712-746X-2021-46-3-602-604

\title{
Межевание и ремонт как индикаторы социального капитала
}

\author{
Виноградский В.Г. \\ Российская академия народного хозяйства и государственной службы \\ при Президенте Российской Федерации \\ Россия, 119571, Москва, пр-т Вернадского, 82 \\ E-mail: vgrape47@yandex.ru
}

\begin{abstract}
Аннотация. Автор рассматривает проблематику консолидации городских сообществ, основываясь на собственных экспедиционных наблюдениях практик консолидации и роста социального капитала в сельских сообществах, а также при проведении въездного квартирного ремонта в городе. Сравнивая повседневные практики соседской взаимопомощи в деревне и городе, автор демонстрирует примеры действенного функционирования того своеобразного «инструментария» накопления и «ремонта» социального капитала, который исправно работает как в сельских, так и в городских сообществах.
\end{abstract}

Ключевые слова: социальный капитал, солидаризация, феномен соседства, сельские домохозяйства, городской квартирный ремонт, «орудия слабых»

Благодарности: работа подготовлена при поддержке Института прикладных экономических исследований РАНХиГС, Центра аграрных исследований и выполнен в рамках Госзадания, НИР «Фермерство России: дифференциация и интеграция».

Для цитирования: Виноградский В.Г. 2021. Межевание и ремонт как индикаторы социального капитала. NOMOTHETIKA: Философия. Социология. Право, 46 (3): 602-604. DOI: $10.52575 / 2712-746 \mathrm{X}-2021-46-3-602-604$

\section{Marking the Land and Repair of the Apartment as Indicators of Social Capital}

\author{
Valery G. Vinogradsky \\ The Russian Presidential Academy of National Economy and Public Administration \\ 82 Vernadsky Avenue, Moscow, 119571, Russia \\ E-mail: vgrape47@yandex.ru
}

\begin{abstract}
The author considers the problems of consolidation of urban communities, based on his own expeditionary observations of the practices of consolidation and growth of social capital in rural communities, as well as during the entrance apartment renovation in the city. Comparing the daily practices of neighborly mutual assistance in the village and the city, the author demonstrates examples of the effective functioning of a kind of "toolkit" for the accumulation and "repair" of social capital, which regularly works both in rural and urban communities.
\end{abstract}

Keywords: social capital, solidarity, neighborhood phenomenon, rural households, urban apartment renovation, "tools of the weak".

Acknowledgements: the work was prepared with the support of the Institute of Applied Economic Research of the RANEPA, the Center for Agrarian Research and was carried out within the framework of the State Assignment, R\&D "Farming in Russia: Differentiation and Integration".

For citation: Vinogradsky V.G. 2021. Surveying and Repair as Indicators of Social Capital. NOMOTHETIKE: Philosophy. Sociology. Law series, 46 (3): 602-604 (in Russian). DOI: 10.52575/2712-746X-2021-46-3-602-604 
Введение. Речь пойдет об урбанизированной среде жизни, но начнем не от городского, а от деревенского сообщества. В изданной Теодором Шаниным в России 30 лет назад замечательной хрестоматии «Великий незнакомец: крестьяне и фермеры в современном мире» есть крохотная, но много объясняющая статья египетского крестьяноведа Генри Хабиба Айрота под названием «Крестьянство как соседство». Там он среди прочего пишет: «Деревня, но ни в коем случае не дом, составляет саму сущность бытия; община во многих случаях более важна, чем семья или род».

И далее: «Однажды автор этих строк на уроке в деревенской школе нарисовал на доске контур домика (это был тест на наблюдательность) и спросил:

- Ну, а теперь, дети, что мы должны добавить, чтобы получился настоящий дом?

- Дверь! Окна! Лестницу! - начали выкрикивать ребятишки. И когда мы сочли рисунок домика полностью завершенным и начали стирать разросшийся рисунок, одна малышка закричала:

- Нет, здесь кое-чего не хватает!

- И чего же?

- Соседей» ${ }^{1}$.

Одним этим словом восприимчивый ребенок смог схватить и отразить не столько наличие физических акторов деревенской повседневности, но и то, что в социологической науке принято называть терминологической связкой «социальный капитал».

Практики деревенской солидаризации. В современной деревне такие феномены продолжают иметь место. Буквально две недели назад, работая в очередной крестьяноведческой экспедиции в одной из кубанских станиц, я записал аналогичный по смыслу нарратив. Мне было подробно рассказано о проявлениях соседской солидарности в недавней весьма активно происшедшей кампании междворового межевания. Несмотря (и даже порой вопреки) на четкую, тщательно задокументированную и, как правило, геометрически прямолинейную разбивку приехавшим районным землемером смежных огородов и иных дворовых зон, соседи систематически, уже post faktum, приватно договаривались всячески смягчать непререкаемость межевых стрелок. Соседи взаимно соглашались на сохранение давних, принятых ранее, границ и разделений приусадебной земли. И даже изобретательно производили «неправильные», то есть более прихотливые, лишенные формальности, рисунки межевания. Последние казались им более органичными, поскольку выходили из глубин давно сложившихся хозяйственных практик отцов и дедов. Соседи продуманно и толково уступали земельные клочки «здесь» и добирали их «там». И это есть действенные формы соседской солидаризации, в глубине которой кроется накопленный десятилетиями хозяйственных практик социальный капитал.

Однако кое-что в такого рода отношениях, разумеется, закончилось. Так, постоянно практикуемые еще только одно поколение назад деревенский «помочи», выражающиеся, как правило, в выделке глиняно-соломенных стройматериалов (саманов) и последующем, буквально ударном, однодневном строительстве саманных хат и сараев, уже окончательно ушли в прошлое.

Таким образом, деревенское соседство (за немногими исключениями) - феномен, исполненный функциональности. Оно работает на сохранность сельского мира. Ведь по сути неофициальное межевание - это акт покоя и согласия. И наоборот, упор на непререкаемость соблюдения формального отмеривания сантиметров огорода, сада, лужайки есть заявление о заведомой конфликтности и недружественности. Это акт обнуления и распыла любого социального капитала. Такова - пока что! - нынешняя деревня.

Практики городской солидаризации. Теперь вернемся в города, в городское социальное пространство. Соседство в городе - это, в сущности, эфемерида. Однако в го-

${ }^{1}$ Великий незнакомец: крестьяне и фермеры в современном мире: Пер. с англ. Сост. Т. Шанин. 1992. М., «Прогресс-Академия», 432 с. 
родских жизненных практиках время от времени возникают мизансцены, в которых пробивается, а порой и стремительно копится социальный капитал. Родители, наблюдающие за играми малолетних детишек на обильно расплодившихся, разноцветных и довольно скучных в своей стандартности игровых придомовых площадках чаще всего начинают дружить и по-соседски общаться.

Но более примечательны в плане перспектив солидаризации мизансцены городского въездного ремонта. Именно здесь возникают довольно продуктивные и, что важно, не досугово-развлекательные, а продуктивные, точнее, продуцирующие, сначала технологические, а потом и социально-культурные связи.

По нашим наблюдениям, только часть ремонтных квартирных операций выполняется наемными специалистами (в основном, это электрика). Устройство сантехнических приборов, черновой напольной стяжки, даже плиточные работы производятся самими квартирными владельцами, тем более что инструмент для этих несложных работ вполне доступен. Соседи постоянно общаются, обмениваются опытом, инструментом, делятся оборудованием, лишними и остающимися строительными материалами. Они часто, кооперируясь, совместно устраивают системы наблюдения за безопасностью лестничных площадок, оборудуют колясочные, сушилки, сберегающую арматуру для велосипедов, самокатов, колясок еtс. Так разрушается целый ряд барьеров консолидации в областях победившего урбанизма. Так копится и умножается социальный капитал.

Относительность происходящего (заключительные замечание). Разумеется, эта картина дискретна. Есть масса примеров соседской ненависти и непримиримости. Чего только стоят спецприспособления для лишения соседей ночного покоя. Насколько изобретательны умельцы, выкладывающие в Сеть технологии и оборудование для «звуковых войн и интервенций»!

Деревенским аналогом подобной отверженности может служить вежливое равнодушие приезжих городских дачников. Именно оно выступает как искаженная, отрицательная, минусовая зона социального капитала и солидарности.

Итак, «инструментарий» накопления и «ремонта» социального капитала как в сельских, так и в городских сообществах имеется. Только надо знать, где именно он лежит и как работает.

Конфликт интересов: о потенциальном конфликте интересов не сообщалось.

Conflict of interest: no potential conflict of interest related to this article was reported.

\section{ИНФОРМАЦИЯ ОБ АВТОРЕ}

Виноградский Валерий Георгиевич, профессор, ведущий научный сотрудник Центра аграрных исследований Института прикладных экономических исследований РАНХиГС при Президенте РФ, Москва, Россия

\section{INFORMATION ABOUT THE AUTHOR}

Valery G. Vinogradsky, Professor, Leading Researcher, Center for Agrarian Research, Institute for Applied Economic Research, RANEPA, Moscow, Russia 